\title{
Zpráva z kongresu European Society for Vascular Surgery 2013 v Budapešti
}

Ve dnech 18.-21. záŕí 2013 jsem se aktivně zúčastnil výročního kongresu European Society for Vascular Surgery (ESVS) s názvem „XXII. Annual Meeting of European Society for Vascular Surgery" v Budapešti. Na kongresu bylo vybráno a prezentováno jen 42 sdělení z celkového počtu 740 přihlášených prací, co svědčí o vysoké úrovni tohoto odborného setkání. Práce s názvem „Reinforced aneurysmorrhaphy for true aneurysmatic haemodialysis of vascular access" autorů S. Rokošný, P. Baláž, P. Wolhfahrt, D. Palouš, L. Janoušek z IKEM byla prezentována ve vědecké sekci formou přednášky. Výše uvedená práce byla na evropském kongresu jako jediná prezentace autorů z České republiky.

Kongres celkově nabízel možnost účastnit se sedmi vědeckých sekcí a symposií (venózní onemocnění karotid, aneurysma aorty, cévní nemoci dětského věku, cévní komplikace, cévní přístup a končetinová ischemie), kde kromě jiného byly prezentovány dlouho očekávané výsledky prospektivních studií. Z přednášek vyplývá že, trendem současné evropské cévní chirurgie je provádění endovaskulárních výkonů cévním chirurgem, a to zejména v léčbě onemocnění aneurysmatu aorty a tepen dolních končetin. Na kongresu byla poprvé prezentována i dlouho očekávaná nová doporučení pro cévní přístupy u hemodialyzovaných pacientů „Guidelines of European Society for Vascular Surgery for AV access".

Kongresu jsem se účastnil za finanční podpory České společnosti kardiovaskulární chirurgie, která mi poskytla cestovní grant na úhradu registrace, dopravy a ubytování. Touto zprávou bych rád oficiálně poděkoval České společnosti kardiovaskulární chirurgie za možnost účastnit se tak významné odborné akce.

MUDr. Slavomír Rokošný, Klinika transplantační chirurgie, Institut klinické a experimentální medicíny, Praha, e-mail: slavomir.rokosny@ikem.cz 